DOI: https://doi.org/10.24297/jssr.v15i.8604

\title{
The Supportive Role of School Management on The Work Satisfaction of Male Teachers in A South African School District
}

\author{
Paul Karel Triegaardt, Jean-Pierre Hugo
}

Department of Education Leadership and Management, College of Education, University of South Africa, P.O Box 392, Pretoria, 0003, South Africa,

Nelspruit Primary School, Mpumalanga Department of Education, P.O Box 274, Nelspruit, 1206, South Africa.

$$
\text { paul.triegaardt@gmail.com,jp_hugo@hotmail.com }
$$

\begin{abstract}
The paper focused on a specific research group (male teachers); firstly because of the shortage of male teachers in South African schools, and secondly, because male teachers are more dissatisfied in their overall work environment than female teachers. This study aimed to investigate, from an educational management perspective, the factors that influence job satisfaction amongst male teachers in schools in a sampled school district in Mpumalanga province. Throughout the study, it became apparent that male teachers are more likely to leave the South African education system than their female counterparts.

A quantitative research approach was used to investigate factors affecting job satisfaction amongst male teachers distributing Likert-scale questionnaires amongst male teachers in selected schools in the district. The results of the study provide an outline of the crises that teachers in South Africa schools are facing, while the statistics and information portrayed in this study help to paint a picture of their work environment. A shortage of teachers, increasing learner enrolment and work overload are enough to create a highly stressful profession. Aspects identified as factors that affect job satisfaction amongst male teachers are the professional development of teachers, capacity building of teachers through collaboration and teamwork, effective support systems to teachers by management, workload of teachers, effective leadership of the principal, effective management of learner behaviour, positive work experiences by teachers, emotional distress of teachers and positive feelings towards teaching as a profession.
\end{abstract}

Keywords: Communication. Former Model-C Schools. Job Satisfaction And Dissatisfaction. Rural Schools. School Leadership And Management. Teacher Support And Empowerment. Work Environment.

\section{Introduction}

Balfour (2013:1) estimates that more than 55\% of teachers in South Africa have considered leaving the profession. Unfortunately, the available statistics regarding South African teachers leaving the profession was out of date and attempts to retrieve newly updated data from the Department of Basic Education were inconclusive. Wallin and Boggan (2015:34) Smit and Du Toit (2016:1) affirm that approximately 50\% of new teachers will leave the profession within the first five years because of the overwhelming workload that they experience. Aliakbari (2015:2) and Msuya (2016:9) outline that teachers establish the basis of a successful education system and that education is one of the main pillars of sustainable development, a country's education system is located at the core of human society, of which the main goal is to train proficient young children and adolescents.

Principals are appointed as managers, and they have the responsibility to manage and maintain a positive climate in which education can take place (Maforah \& Schulze, 2012; California County Superintendents Educational Services Association, 2016:16). The previous statement is supported by the findings of Meador (2019) who indicated that a good principal should be positive, enthusiastic, have his hand in the day-to-day 
activities of the school, and listen to what his constituents are saying. A principal's influence on the teacher's performance is exerted in the manner that principals think, speak and practise what they preach. The influences are based on the way in which leaders commit themselves to apply their values, principles, beliefs, moral convictions and attitudes towards teaching and learning so that their actions speak louder than words (Marishane \& Botha, 2011).

Effective principals serve as mentors, a support base, a source of information and role models for teachers, which can have a direct impact on staff morale (Steyn \& Van Niekerk, 2008), while teachers need to ensure the quality of the teaching, learning activities, distribution of work and learner performance (Van Deventer \& Kruger, 2011; Tetik, 2016; Brill, Grayson, Kuhn, \& O'Donnell, 2018). The learning environment of a school depends on teachers because they are in the frontline and directly involved with the transfer of knowledge. Teachers have a direct impact on a school's success, and it is, therefore, important that principals identify ways to support their staff in order to promote job satisfaction and motivation.

\section{Literature Review}

A literacy study was undertaken to address the topic of job satisfaction among male teachers in former Model$\mathrm{C}$ and rural schools. The literature will focus on factors regarding job satisfaction and their interaction with education. In order to evaluate the impact that school management has on the work satisfaction of male teachers, a review of literature was conducted on the elements discussed below.

\subsection{The result when teachers experience job satisfaction}

Job satisfaction is defined as an enjoyable or positive emotional condition that a person has towards his or her job, which is caused by an emotional response to the circumstances of a job (Salehi \& Taghavi, 2015:14; Hutabarat, 2015:295). All types of managers are continuously faced with one common challenge, namely, to motivate employees to work towards achieving the organisational goal (Buchbinder \& Shanks, 2007). Motivation is defined as an "internal state that arouses, directs and maintains behaviour" (Woolflok, 2010:376). It is the driving force behind our actions and work (Shah et al., 2012).

When staff is motivated in their work environment, they may experience a drastic increase in job satisfaction, confidence and a degree of fulfilment. Lifting the morale of a teacher causes them to experience a positive climate, and it creates a pleasant learning environment for the children (Van Deventer \& Kruger, 2011). By identifying the factors that improve teachers' motivation and morale, principals can implement and execute effective strategies to ensure that teachers, amid these changes, will perform their duties in an effective, enthusiastic and motivated manner (Steyn \& Van Niekerk, 2008; Msuya, 2016:10; Gina, 2018). Therefore, it was important to identify aspects to keep staff motivated and loyal to the system.

\subsection{The benefit of communication}

According to Steyn and Van Niekerk (2008), great leaders, including great school leaders, use a powerful tool, namely communication, and when leaders fail to communicate their staff will misinterpret, misunderstand and receive mixed messages. Principals must understand the complexity of communication in order to coordinate activities and help teachers to put objectives into practice in their work environment (Ärlestig, 2007; Glover, Nugent, Chumney, Ihlo, Shapiro, Guard, Koziol \& Bovaird, 2016). The flow of information and ideas can be 'top down', from the 'bottom up' and 'horizontal'. These channels of communication are described below (Van Deventer \& Kruger, 2011):

- Downward channels: This information flows from the principal to the staff, and the purpose is to direct the behaviour and coordinate who receives the information (Van Deventer \& Kruger, 2011). 
- Upward channels: The communication flows upward from the teachers to the management (Van Deventer \& Kruger, 2011). This type of communication is encountered where teachers are involved in the decisionmaking process, as indicated previously.

- Horizontal channels: Horizontal communication occurs between people on the same level of the school's organisational structure, e.g. between teachers or between management staff (Van Deventer \& Kruger, 2011).

It is important to realise that without communication, people become demotivated, which will create an unpleasant work environment among teachers (Steyn \& Van Niekerk, 2008; Glover et al. 2016). This provided the researcher with the structure of communication for teachers to know what is expected of them and how they rely on the principal to guide them towards achieving an effective work environment. Principals, teachers, parents and learners are all involved in the process of communication, which could cause a communication gap. Therefore, it is the responsibility of school principals to make sure each person involved understands the message clearly (Carl, 2010; Naidoo \& Petersen, 2016; Mestry, 2017).

\subsection{Professional empowerment of teachers}

Steyn and Van Niekerk (2008) cite a definition of empowerment by Matjeka, Dunsing and McCabe (1999) as the process by which staff are entrusted the power (authority) to make decisions and take actions relating to assigned tasks; staff's involvement in the creation of ways of maintaining a productive and satisfying work environment and their involvement in daily problem-solving and decision making.

Belle (2007) has found that teachers experience job satisfaction and high levels of motivation when they have some measure of control over their work environment through empowerment, this might involve participation in decision-making and providing them with different types of roles where they experience a sense of belonging and recognition. In retrospect, Carl (2010), Belle (2007) and Mestry (2017) acknowledge that by empowering teachers, principals enable them to become effective leaders in their classrooms and other academic areas.

\subsection{The benefit of involving teachers in the functionality of the school}

Swanepoel (2008) indicates that by sharing in the responsibility of decision-making will encourage teachers to address educational problems and that school principals had significantly underestimated the willingness of teachers to be involved in decision making. "Teacher participation in decision making is one of the recommendations of management and one of the key characteristics of an effective school." (Cheng, 2008) Principals need to realise that teachers are in the frontline and can give insight into the problems that the school might be facing (Omobude \& Igbudu, 2012).

Mualuko, Mukasa and Judy (2009) state that management who makes decisions on their own will have a negative effect on efficiency and productivity of the schools because teachers work at half steam because they are not effectively involved in decision making to make them feel like part of the school. Latif et al. (2011) Naidoo \& Petersen (2016) and Glover et al. (2016) found that the involvement and commitment of teachers are one of the most important factors that have an impact on the job satisfaction of teachers.

\subsection{The importance of a functional work environment}

Leithwood (2006) and Berry, Smylie and Fuller (2008) state that the performance and attitude of teachers will be influenced positively or negatively by their work environment. This will affect their job satisfaction and commitment toward their school. As indicated by Azeem (2010), employees who are committed to the organisation and satisfied with their work environment are high performers, reducing staff turnover. Teachers who enjoy their work environment will be well-performing teachers (Shah et al., 2012), innovative and motivated to establish and maintain an environment conducive to learning (Schulze, 2006). 
Quan-Baffour and Arkon-Achemfour (2013) have found that teachers at South African schools who experience poor conditions of service, increased workload, lack of discipline among learners and violence against teachers in their work environment will lead to frustration and they might leave the profession. As indicated by QuanBaffour and Arkon-Achemfour (2013) and Shihundla, Lebese and Maputle (2016:1), the workload is one of the factors that have a definite impact on the job satisfaction of teachers.

\subsection{Ongoing support}

Research done by Fuller, Young and Baker (2011) indicates that the relationship between a principal and his or her staff has a definite influence on the job satisfaction of teachers and according to Edgerson and Kritsonis (2006), "principals have the ability to improve teacher perceptions overall by simply attending to fundamental components inherent in quality relationships". They have also established that teachers and principals can work together by forming a professional relationship to identify and resolve factors that might have a negative impact on the school environment.

As indicated in the section about 'communication between management and teachers', communication is an effective tool that principals can use to gain information from teachers, and the effectiveness of communication may promote the relationship between a principal and his or her staff. Marishane and Botha (2011) emphasise that principals can inspire teachers by developing a positive relationship, which creates an atmosphere of mutual trust and sustained support by showing interest in what teachers do.

\subsection{Result when teachers experience job dissatisfaction}

Emsley et al. (2009) state that male teachers in South Africa are more likely to leave the education system because of low job satisfaction and an unpleasant work environment. Satisfaction in a person's work environment can be influenced by factors such as pay, the work itself, supervision and relationships with coworkers, management, and opportunities for promotion (Hasbay \& Altındag, 2018; Corkin, Ekmekci \& Parr, 2018). Herzberg, Mausner and Snyderman (1993) mention that the main reason why employees are unhappy in their work is directly related to the environment in which they work, which has a direct impact on morale.

Khalil (2013) indicates that work morale and job satisfaction are directly related to each other. Previous statements have mentioned that there are factors that influence the work environment of teachers negatively; therefore, it is important to recognise that teachers' morale is affected by these factors and that it has a definite impact on their job satisfaction (Steyn, 2002; Corkin et al. 2018). When employees are unhappy, the employer has to put up with unmotivated staff and consequently reduced productivity (Buchbinder $\&$ Shanks, 2007).

In the case of education, productivity can be seen as the transfer of knowledge and information from the teacher to the learner, which is the primary function of the teacher and school (Saeed \& Muneer, 2012). The involvement and commitment of teachers are some of the most important factors that contribute to promoting job satisfaction (Latif et al. 2011). Promoting job satisfaction among men in the education system is extremely important because of the drastic increase in migration to other countries and the private sector.

These problems should be addressed to ensure that there is a future presence of male teachers in South African schools (Van Zyl, 2011). By evaluating job satisfaction and motivation of teachers, the researcher was able to identify factors that have a positive impact on their work environment. The school that aims to promote job satisfaction will be familiar with open communication between management and teachers to encourage a positive atmosphere in the workplace. According to Corkin et al. (2018), the performance of teachers in their workplace can be enhanced by improving motivation.

\subsection{Conclusion}

The school that aims to promote job satisfaction amongst staff will be familiar with open communication between management and teachers to encourage a positive atmosphere in the workplace. This study was 
conducted to provide school management with the necessary support strategies to enhance job satisfaction amongst male teachers which will enhance the performance of male teachers in their workplace. The previous goal is in line with the research question provided in this which will be discussed next.

\section{The Research Question}

Principals and teachers are powerless to change the requirements set by the Department of Education, but principals can restructure the system within the school environment to utilise the teacher's full potential and achieve job satisfaction. The role of a principal in promoting job satisfaction among male teachers will be a key concept when focusing on the support strategies. The extent of job satisfaction differs from one school to another. It was for this reason that the researcher focused on rural and former Model-C schools. The problem statement, to be phrased as a research question, is as follows: Which support strategies given by principals may enhance job satisfaction amongst male teachers in the Ehlanzeni school district of Mpumalanga?

The study was guided by the following sub-problems:

- What does job satisfaction in the workplace entail?

- Which factors influence job satisfaction in an educational setting?

- How could a school principal enhance job satisfaction among male teachers?

- Which support strategies by principals have a positive impact on the job satisfaction of male teachers?

- How can the promotion of job satisfaction be conceptualised as a support strategy in the Ehlanzeni school district of Mpumalanga to ensure that male teachers stay in the profession?

Having stated the research problem and sub-problems, the aims and objectives pertaining to the improvement of job satisfaction were formulated in order to help the study to focus more clearly on the problem.

\section{Aims and Objectives with the Study}

The main objective of the study was to improve job satisfaction among male teachers in the school environment through principals providing support to male teachers. These support strategies would provide motivational methods that enable the principal to deal with the teacher on a level that promotes job satisfaction. The following sub-aims were identified for this study:

- To define job satisfaction in the workplace;

- To identify factors which influence job satisfaction in an educational setting;

- To explore how a school principal may enhance job satisfaction among male teachers;

- To establish support strategies by principals may have a positive impact on the job satisfaction of male teachers;

- To explain how the promotion of job satisfaction should be conceptualised as a support strategy in the Ehlanzeni school district of Mpumalanga to ensure that male teachers stay in the profession.

\section{Research Methodology}

\subsection{Research population and sample}


The target population comprised of male teachers in the Ehlanzeni school district in the province of Mpumalanga in South Africa. Only male teachers participated in the study because there is a dire need of male teachers in the South African education system and the poor retention rate of male teachers as indicated in the introduction. The respondent in the study had teaching experience between one and thirty years. For this study, the sample size was 146 male teachers, which was $73 \%$ of the actual complement of 200 . The researcher made use of the quantitative research approach during the data collection process. The quantitative research approach comprises the steps that a researcher needs to take by obtaining information from people with insight into the topic that is researched in order to answer the research question. One of the common ways to obtain information from subjects is a questionnaire.

\subsection{Data collection procedures and research instrument}

The primary data were collected through a structured questionnaire that was distributed by hand to all participants. Participants were asked to complete it anonymously, to ensure that responses received were truthful and completed honestly. Nominal scales were used to categorise the variables in Section A of the questionnaire.

Respondents were grouped according to years' teaching experience, highest academic qualification, present position occupies in the school, number of learners in school, number of learners in class, the geographical location of school and type of school. Section B was used to gather information on relationships management and teacher work satisfaction; factors facet influencing teacher morale and factor facets impeding teacher work satisfaction. The responses from Section B were scored on a six-point Likert scale, ranging from 1, strongly disagree to 6 , strongly agree.

The questionnaire had a covering letter with instructions on how to complete it and the reasons it was being conducted. It also assured the respondents of the confidential nature of the research and stated that the respondents were free to main anonymous if they wished.

\subsection{Data analysis and presentation}

The data collected were analysed using descriptive statistics, which included frequencies and percentages in order to answer the research questions. The descriptive method is used to indicate the spread of a sample across a wide range of variables (De Vos et al., 2012:251). In other words, the Likert-scale questionnaire helped the researcher to indicate on which level most male teachers feel the same about an assumption of a question. Frequency distribution quickly indicates the most and least (number of times) frequently occurring score (McMillan \& Schumacher, 2010:152-153). Percentile rank refers to when the analysis indicates that a certain percentage of the score is at, or below a particular score (McMillan \& Schumacher, 2010:162).

The original Likert-scale questionnaires and statistics were securely stored in hard copy (paper) and on a computer. A backup was made on a CD in case the information on the computer or the hard copy was lost or damaged. The data gathered during the data collection process will be stored for a minimum of five years. All the procedures mentioned above enabled the researcher to present data efficiently and effectively.

\subsection{Ethical issues}

The researcher provided participants with a participant information sheet attached to the Likert-scale questionnaire. The participant information sheet provided the participant with the name and purpose of the study, what was expected of them and gave assurance of anonymity and confidentiality. The information sheet indicated what the researcher entailed to do with the information gathered during the data gathering process.

The contact details of the researcher were available on the information sheet; this allowed the participants to contact the researcher if they had any queries or requested access to the results and outcome of this study. Participants were informed that they had the right to decline participation without any adverse consequence. 


\section{Biographical Data of the Participants}

\subsection{Years teaching experience}

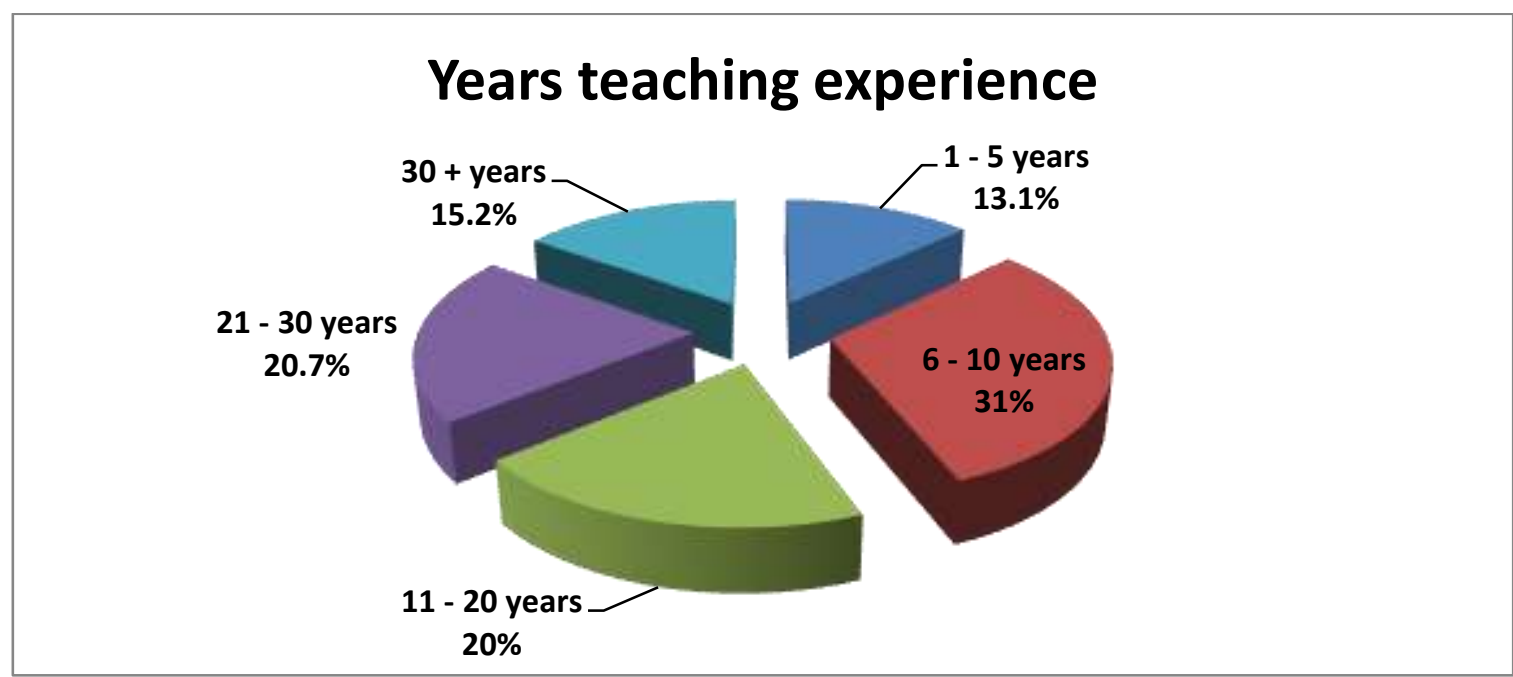

Figure 1: Teaching experience of respondents

The sample indicated that the majority of respondents surveyed belonged to the 6 to 10 years' teaching experience category (31,0\%). Murage and Kibera (2014:149) have found that teachers with more experience are more satisfied with their work than the least experienced teachers are. Only $13,1 \%$ of respondents in this study reported one to five years' experience. The sample indicated that $55,9 \%$ of the respondents have more than ten years' teaching experience. This indicates that the participants have a lot of experience regarding the educational environment. The statement mentioned above can be supported by the findings of Murage and Kibera (2014), Glover (2016) and Heiney-Smith and Denton (2015) that age and experience have a significant effect on job satisfaction, with older workers having greater satisfaction with their work than young workers have. $15,2 \%$ of the sample are male teachers with more than 30 years' teaching experience.

\subsection{Highest academic qualification}

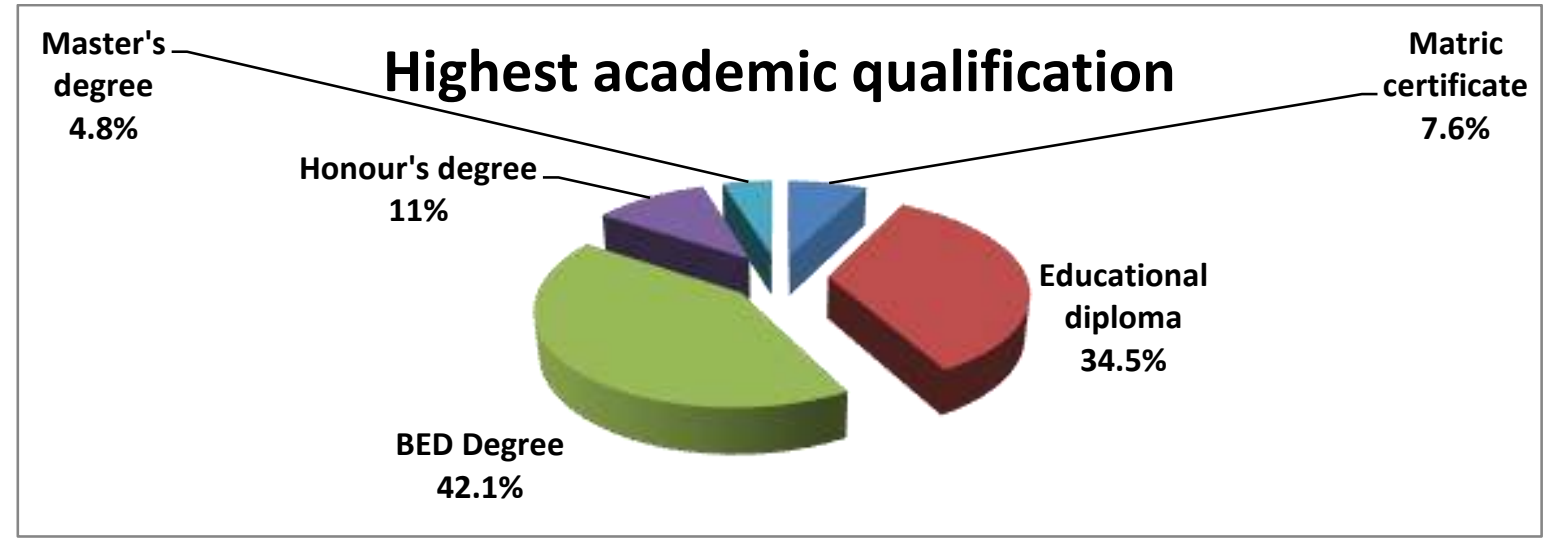

Figure 2: Highest academic qualifications

The majority of the respondents that participated in the study indicated that they possessed a Bachelor of Education degree $(41,8 \%)$, while $15,8 \%$ had an honours degree or higher educational qualification. Research done by Murage and Kibera (2014:151) and Shaukat, Vishnumolakala and Al Bustami (2018) has found that the different academic qualifications of teachers do not have a significant influence on the job satisfaction of teachers; this indicates that with a Master's degree or a BEd degree, a teacher will still experience job satisfaction 
or dissatisfaction in the same way. The majority of the respondents $(92,4 \%)$ in the survey are qualified teachers. The other 7,6\% of the respondents have a Grade 12 qualification. As indicated in Chapter 2.5.7, Butali et al. (2013:67) describe that replacing an experienced worker with a new staff member will cause a dramatic drop in productivity.

\subsection{Present position occupied in the school}

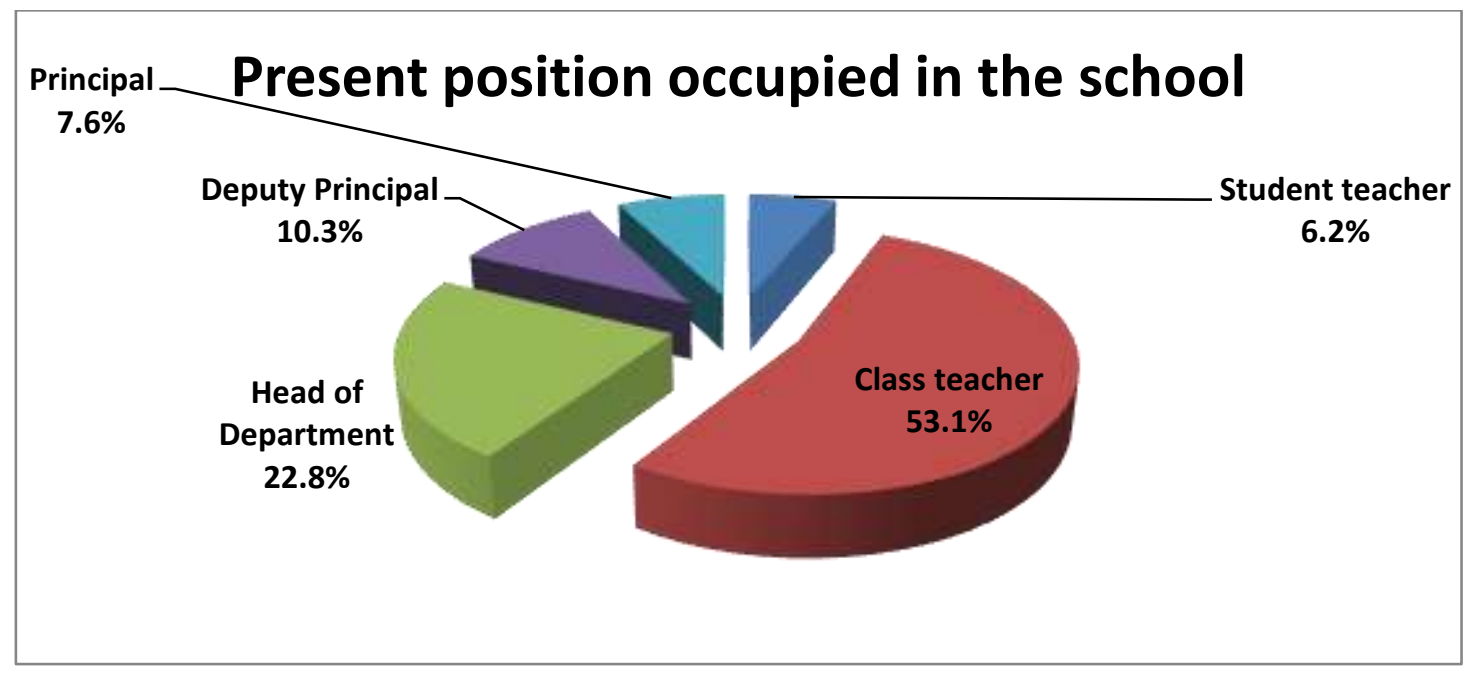

Figure 3: Present position occupied in the school

The majority of respondents $(53,1 \%)$ indicated that they were class teachers, while $22,8 \%$ were heads of departments, and 17,9\% were deputy principals or principals. According to Nganzi (2014:16) and Shaukat et al. (2018), the educational status and teaching responsibilities of teachers are determining factors of the job satisfaction of a teacher. Steyn and Van Niekerk (2008:149) indicate that empowering someone with certain responsibilities and power will create a satisfying work environment for the percentage that is empowered, affirming that as a person progresses through the school system, they will experience more satisfaction. The lowest percentage (6,2\%) was accumulated by student teachers. Kiggundu and Nayimuli (2009:345) and Shumba, Rembe, Chacko and Luggya (2016) indicate that the challenges that student teachers experience may affect their perception and feeling towards the teaching profession.

\subsection{Type of school}

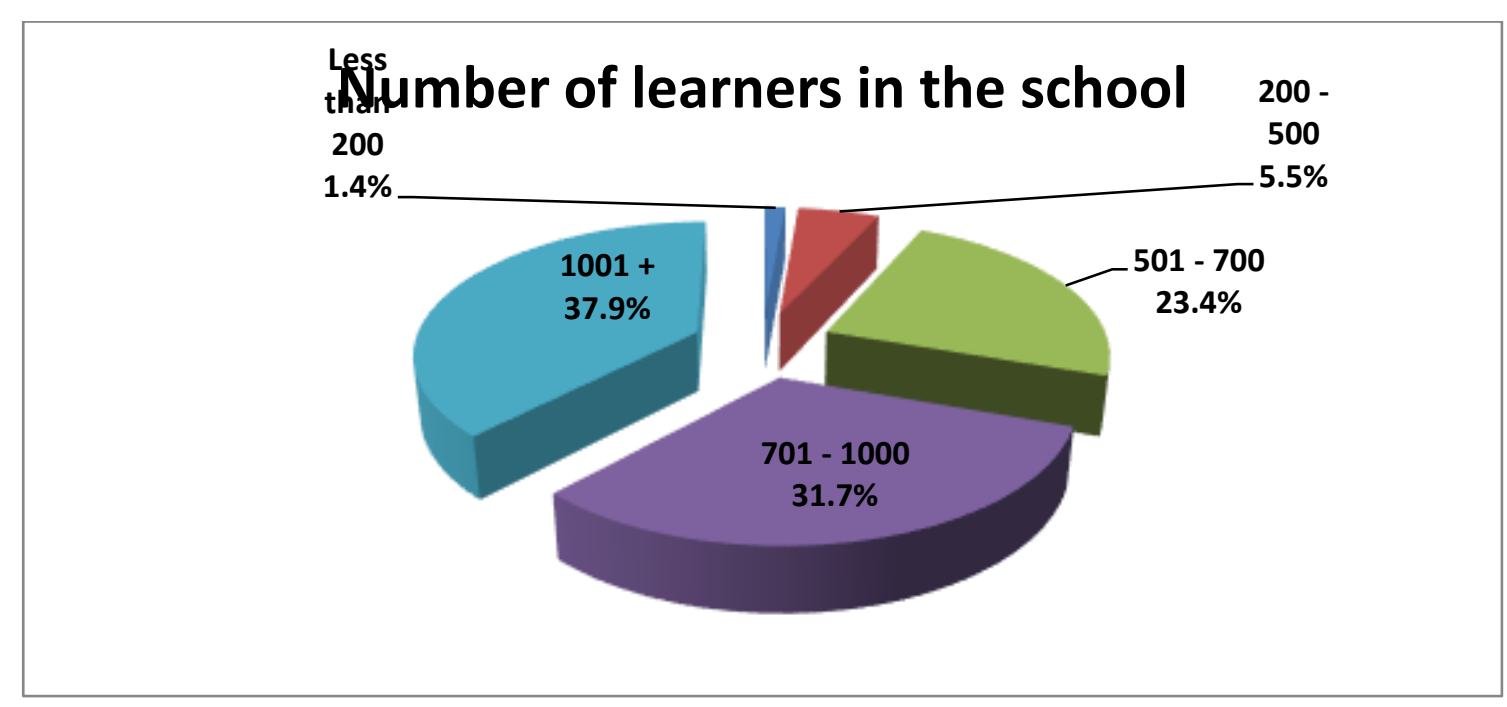

Figure 4: Number of learners in the school 
Most of the respondents were teaching at primary schools $(44,8 \%)$, followed by respondents teaching at secondary schools $(37,2 \%)$ and combined schools $(17,9 \%)$. The vast majority of schools in the Ehlanzeni school district are primary and secondary schools, with only a few combined schools in the district. It is interesting to note that of the 20 participating schools, there were nine primary schools (former Model-C and rural schools), nine secondary schools (former Model- $\mathrm{C}$ and rural schools) and two combined schools and that most of the respondents came from the primary schools. Nganzi (2014:14) notes that teachers at primary and secondary schools will experience motivation and satisfaction in the same manner regarding the factor.

\subsection{Number of learners in your class}

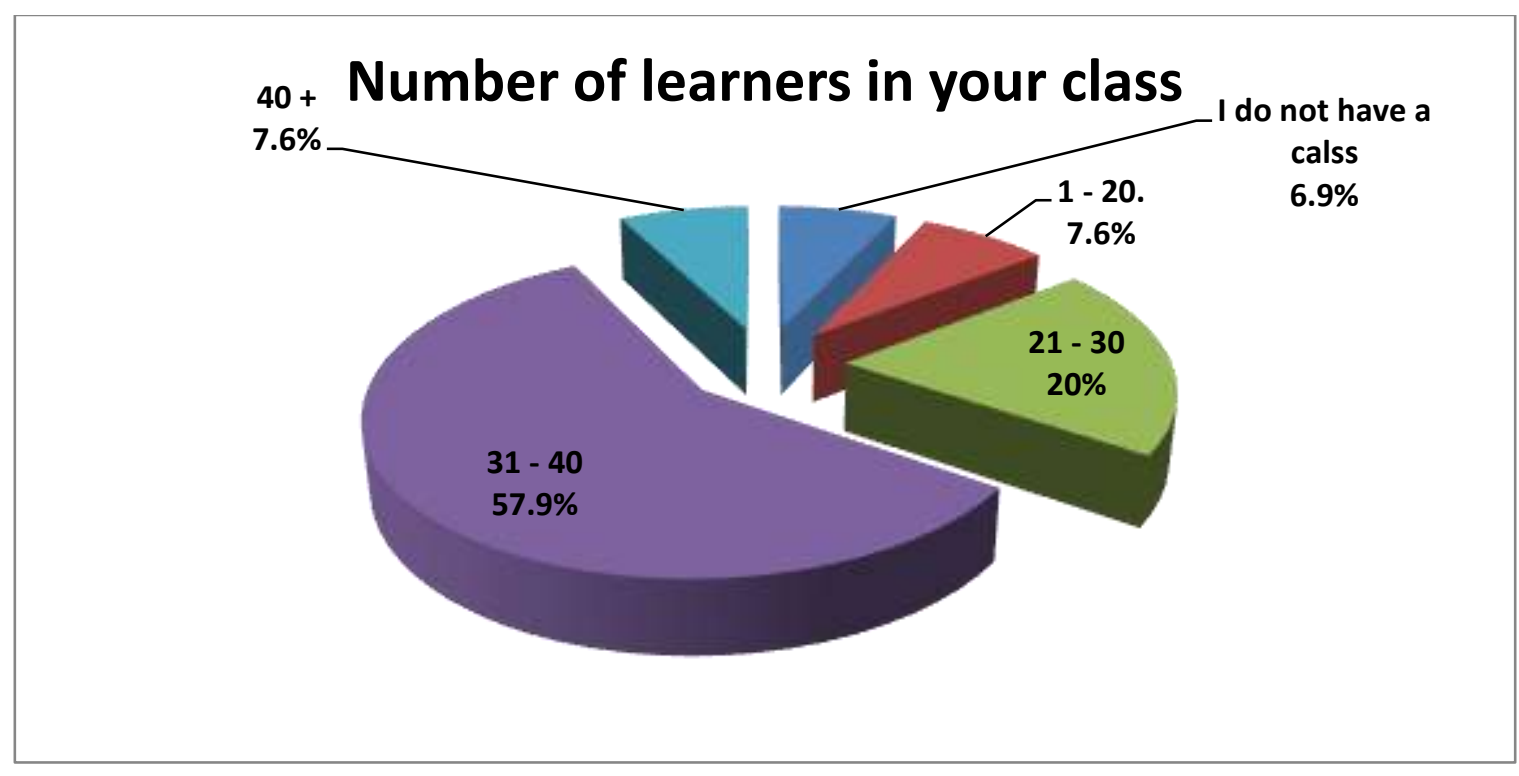

Figure 5: Number of learners in your class

The "I do not have a class group" is probably the result of principals being present as they normally do not have a subject- or register class. The overwhelming majority of teachers $(57,9 \%)$ indicated that they had classes with about 31 to 40 learners in their class. It is alarming to observe that 7,6\% of the respondents have to educate more than 40 learners at a time in one classroom; overcrowding in classrooms according to (Iwu et al., 2013:838) is definitely one of the factors affecting the job satisfaction amongst teachers. Moyo, Khewu and Bayaga (2014:1) and Marais (2016) indicate that job dissatisfaction will intensify when teachers are faced with overcrowding in their classrooms.

\section{Analysis and Discussion of the Research Results}

\subsection{Factor analysis}

The investigation of a possible relationship between management and teacher work satisfaction via the perspective of male teachers involved constructs which are latent or hidden. Management and work satisfaction of teachers consist of numerous variables. A correlation matrix obtained via SPSS22.0 indicated that some items were poorly correlated and should be removed.

The Kaiser-Meyer-Olkin (KMO) values for the 40 variables are found on the diagonal of the anti-image correlation matrix, which is the matrix of the correlation coefficients with the signs reversed (Norusis, 2009:395). Eight items with $\mathrm{KMO}$ values less than 0.6 were removed one at a time as the $\mathrm{KMO}$ statistics are influenced by this removal (Field, 2009:659). The KMO value increased from the initial to 0.750, which is regarded as 'middling (Norusis, 2009:394) and the Bartlett's sphericity value was significant $(p=0.000)$. Nine first-order factors explaining $62.95 \%$ of the variance resulted: 
- $\quad$ FB 1.1 - Professional development of teachers.

- FB 1.2 - Capacity building through collaboration and teamwork.

- $\quad$ FB 1.3 - Effective support systems to teachers by management.

- $\quad$ FB 1.4-Workload of teachers.

- $\quad$ FB 1.5 - Effective leadership of the principal.

- $\quad$ FB 1.6 - Effective management of learner behaviour.

- $\quad$ FB 1.7 - Positive work experience by teachers.

- $\quad$ FB 1.8 - Emotional distress amongst teachers.

- $\quad$ FB 1.9 - Positive feelings towards

These nine first-order factors were subjected to a second-order procedure, as the KMO value of 0.749 and a significant Bartlett's value indicated that such a reduction would be viable. Three second-order factors, which explained $58,92 \%$ of the variance, resulted. These factors all had Alpha Cronbach reliability coefficients above the recommended value of 0.7 :

- $\quad$ FB 2.1 - Relationships management and teacher work satisfaction. The average mean scores of 5.34 and Cronbach Reliability of 0.831 indicates that the respondents agreed with the factor.

- $\quad$ FB 2.2 - Facets influencing teacher morale. The average mean scores of 5.30 and Cronbach Reliability of 0.732 indicates that the respondents agreed with the factor.

- $\quad$ FB 2.3 - Impeding teacher work satisfaction. The average mean scores of 4.45 indicate that the participants were in partial agreement with this factor.

If a third-order factor analytic procedure is performed, only one factor is formed. In other words, the three second-order factors of relationship management and work satisfaction (FB2.1), facets influencing teacher morale (FB2.2) and facets impeding teacher work satisfaction (FB2.3) all fall under one factor, which could be named the quality of the working life of teachers (FB3.0). However, as the second-order factors all had satisfactory reliability coefficients, they were used to test the various independent variables.

\subsubsection{Comparison of independent groups with respect to the three independent factors}

As the data distribution in the three dependent variables (factors) was skew, the Mann-Whitney U-tests were conducted because the data are ranked; hence, high scores are represented by large ranks and low scores by small ranks (Field, 2009: 540).

\section{a) Geographical location of the school}

There were two groups, namely rural and urban. Possible hypotheses could be as follows:

Ho - There is statistically no significant difference between the mean ranks of the two school geographical location groups regarding:

- $\quad$ FB2.1 - relationship management and work satisfaction.

- $\quad$ FB2.2 - facets influencing teacher morale. 
FB2.3 - facets impeding teacher work satisfaction.

$\mathrm{Ha}$ - There is statistically a significant difference between the mean ranks of the two school geographical location groups regarding:

- $\quad$ FB2.1 - relationship management and work satisfaction.

- $\quad$ FB2.2 - facets influencing teacher morale.

- $\quad$ FB2.3 - facets impeding teacher work satisfaction.

The results of Mann-Whitney U-test were as follows:

$$
\begin{aligned}
& F B 2.1-\overline{\boldsymbol{U}}_{\text {Rural }}=74.72 ; \overline{\boldsymbol{U}}_{\text {trban }}=71.98 ; \boldsymbol{Z}=-0.381 ; \boldsymbol{p}>0.05 . \\
& \boldsymbol{F B} 2.2-\overline{\boldsymbol{U}}_{\text {Rural }}=69.97 ; \overline{\boldsymbol{U}}_{\text {trban }}=74.80 ; \boldsymbol{Z}=-0.670 ; \boldsymbol{p}>0.05 . \\
& \boldsymbol{F B} 2.3-\overline{\boldsymbol{U}}_{\text {Rural }}=75.03 ; \overline{\boldsymbol{U}}_{\text {trban }}=71.80 ; \boldsymbol{Z}=-0.499 ; \boldsymbol{p}>0.05
\end{aligned}
$$

The results indicate that in all three of the dependent variables, no statistically significant differences could be found between the two geographical location groups and the three factors involved. Hence, the null hypothesis cannot be rejected with respect to any of the three factors. Hence, the effect is not big enough to be anything but a chance finding (Field, 2009:53). It is possible that the sample size was a limiting factor as the sample size of 146 was too small for 40 variables, and a sample of 300 or more would have been preferable.

\subsubsection{Comparing three or more independent groups with one another}

When the data do not meet the parametric requirements, one can use the Kruskal- Wallis $(H)$ test. This test compares the mean ranks of the three groups taken together. Should a significant difference be found, then one would use the Mann- Whitney U-test to test the groups in pairs.

\section{a) Years of teaching experience (A1)}

The Kruskal-Wallis test for relationship management and teacher work satisfaction (FB2.1) was as follows:

$$
\left[\boldsymbol{F B} 2.1-\mathrm{X}^{2}(4)=4.82 ; \boldsymbol{p}>0.05\right]
$$

This indicates that the null hypothesis could not be rejected and that there is statistically no significant difference between the mean ranks of the five age groups taken together. The result is shown in the boxplot of Figure 1.

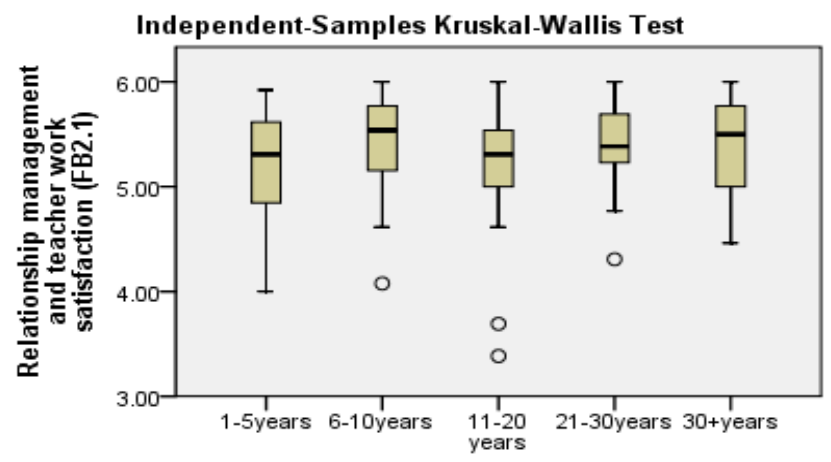

A1. Years of teaching experience 
Figure 6: Boxplot for the years of teaching experience groups regarding relationship management and teacher work satisfaction (FB2.1)

The boxplot in Figure 1 indicates that the median values of the five age groups are relatively similar, and no significant differences could be found between the five age groups. In addition, no differences could be found regarding the other two factors, facets influencing teacher morale (FB2.2) and facets impeding teacher work satisfaction (FB2.3).

\section{b) Highest academic qualification (A2)}

The original five groups were collapsed to three due to small numbers in some of the groups such as a master's degree. The independent Kruskal-Wallis design test indicates that none of the null hypotheses could be rejected, as there are no statistically significant differences between the factor means and the three qualification groups. The Kruskal-Wallis test results were:

$$
F B 2.1-\mathrm{X}^{2}(2)=0.875 ; p=0.646 ; F B 2.2-\mathrm{X}^{2}(2)=5.791 ; p=0.06 ; F B 2.3-\mathrm{X}^{2}(2)=2.781 ; p=0.25
$$

In all three of the factors concerned the $p$-value was larger than 0.05 , and hence the differences in mean scores were too small to be rejected due to chance factors. As the facets influencing teacher morale had the largest differences (although not significant) between the mean scores, these results are shown via a boxplot in Figure 2.

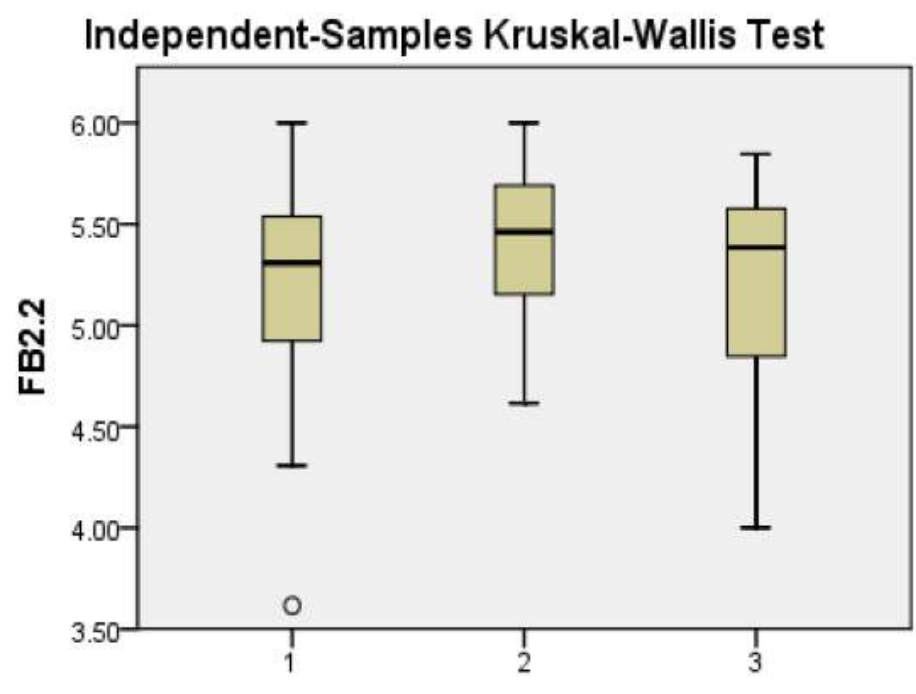

A2.Highest qualification recoded to 3 groups

Figure 7: Boxplot for the highest educational qualification groups regarding facets influencing teacher morale (FB2.2)

The boxplot indicates that the group with the lowest qualifications (matric + education diploma) had the lowest median while Group 2 (Bachelor of Education degree) and Group 3 (Honours or higher) had slightly higher median values. All medians were above the scale value of 5 , indicating agreement with the factor.

\section{c) Present position in the school (A3)}

The original five groups were collapsed to three, namely teachers, heads of department and deputies as well as principals formed the third group. No statistically significant differences could be found in any of the three 
factors regarding the three qualification groups. All three groups agreed with the relationship management and work satisfaction and facets influencing teacher morale factors while partially agreeing with the facets impeding teacher work-satisfaction factor.

\section{d) Number of learners in the school (A4)}

The original five groups were collapsed to three, namely 100 to 700 learners in Group 1, 701 to 1000 in Group 2 and 1001 or more in Group 3. The Kruskal-Wallis test results were:

$$
F B 2.1-\mathrm{X}^{2}(2)=2.744 ; p=0.254 ; F B 2.2-\mathrm{X}^{2}(2)=0.013 ; p=0.993 ; F B 2.3-\mathrm{X}^{2}(2)=1.803 ; p=0.406
$$

As all the probability values were larger than 0.05 , this indicated that the differences were due to chance factors; hence the null hypothesis could not be rejected. All respondents at the three school groups agreed with the factors concerned.

\section{e) Type of school (A7)}

The three school type groups were also tested via the Kruskal-Wallis test, which indicated that possible differences were present. Using the more sensitive ANOVA test indicated that there was a difference in factormean scores between the primary school respondents and the combined school respondents with respect to facets impeding teacher work satisfaction. These results are shown in Table 1

Table 1: Significant differences between the three school type groups regarding the facets impeding teacher work satisfaction (FB2.3)

\begin{tabular}{|c|c|c|c|c|c|c|c|}
\hline \multirow[t]{2}{*}{ Factor } & \multirow[t]{2}{*}{ Group } & \multirow[t]{2}{*}{ Mean } & \multirow{2}{*}{$\begin{array}{l}\text { ANOVA } \\
\text { (p-value) }\end{array}$} & \multicolumn{4}{|c|}{ Hochberg GT2 } \\
\hline & & & & & 1 & 2 & 3 \\
\hline \multirow{3}{*}{$\begin{array}{l}\text { Facets impeding teacher work } \\
\text { satisfaction (FB2.3) }\end{array}$} & Primary & 4.65 & \multirow{3}{*}{$0.031^{*}$} & 1 & & - & * \\
\hline & Secondary & 4.38 & & 2 & - & & - \\
\hline & Combined & 4.09 & & 3 & * & - & 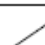 \\
\hline
\end{tabular}

${ }^{*}=$ Statistically significant at the $5 \%$ level $(p>0.05$ but $p<0.01)$

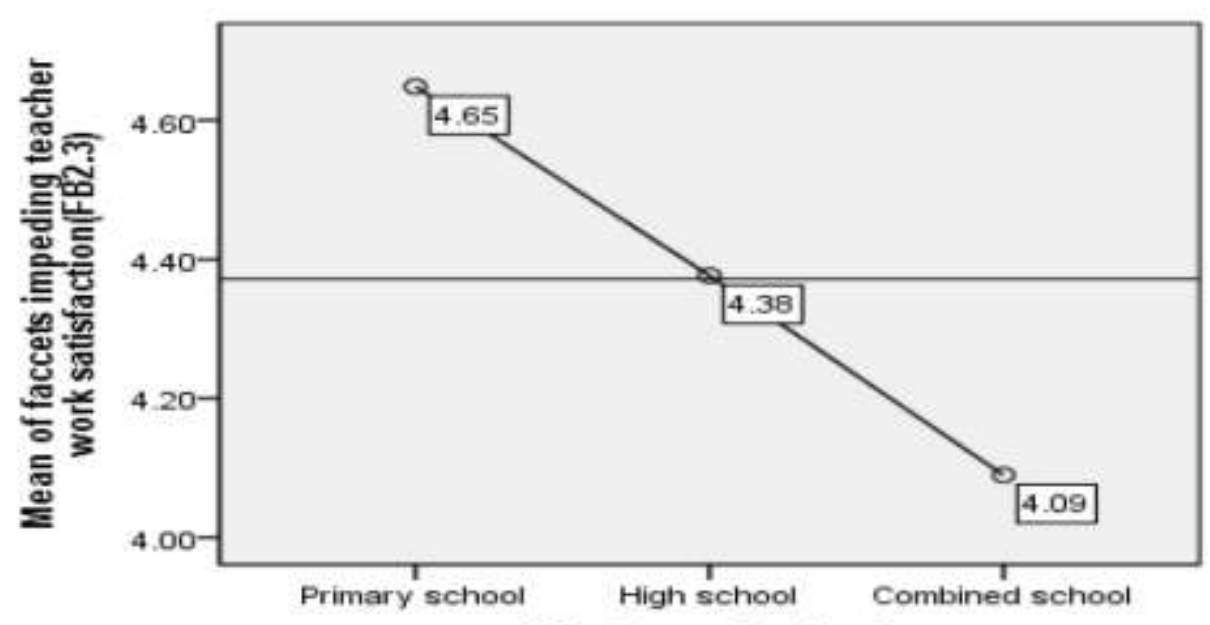

A7. Type of school 
Figure 8: Line graph that indicates the respondents from the combined school teacher

The line graph and the data in Figure 3 indicate that the respondents from combined schools agree statistically significantly less strongly with the facets impeding teacher work satisfaction than respondents from primary schools do. It is possible that primary-school teachers experience the continuous assessment tasks that accompany the CAPS curricula as making excessive demands on their time; hence, they very strongly agree with the impediments factor (Ngobeni, 2006:28).

\subsection{Empirical findings}

Participants indicated that the way they experience their work has a definite impact on their satisfaction in their work environment. The mean score of 5.74 indicates that teachers tended to regard positive work experiences by teachers as the upmost factor and probably crucial when having to decide on reasons why male teachers experienced low-level job satisfaction.

Professional development of teachers was identified as a determining factor regarding the job satisfaction of male teachers. A mean score of 5.4 indicates the professional development of teachers as a very important factor, which definitely contributes to low-level job satisfaction.

The leadership of a principal was identified by participants as a crucial component when evaluating the level of job satisfaction that male teachers experience in their school environment. It is the responsibility of principals to create a pleasurable work environment for male teachers to keep them loyal to their school by being aware of the frustrations that male teachers experience in their work environment. The mean score of 5.37 the effective leadership of the principal was identified as an important factor when having to decide on reasons why male teachers experience low-level job satisfaction.

Capacity building through collaboration and teamwork emerged as an influence on the level job satisfaction that male teachers experience. Principals need to promote relationships at their schools through effective communication, recognition and feedback. The mean score of 5.32 indicates that capacity building thorough collaboration and teamwork contributes to male teachers' experience of low-level job satisfaction.

The majority of the respondents identified effective support systems to teachers by management as an important factor that influences the job satisfaction amongst male teachers. Principals need to identify ways to support their staff through channels of open communication and promote a positive atmosphere in the workplace. The mean score of 5.24 indicates that teachers regard effective support systems to teachers by management as a very important factor and are probably crucial when having to decide on reasons why male teachers experience low-level job satisfaction.

\section{Conclusion}

The purpose of this study was to investigate how school management could support male teachers towards job satisfaction. The study revealed that school management could utilise several determining factors in order to promote the satisfaction of male teachers in their school. These include: implementing a mentorship programme, effective communication, rotating responsibilities between male teachers, delegating leadership responsibilities, providing developmental opportunities, providing guidance to male teachers, workload distribution, supporting male teachers in managing workload, participating in decision-making, principal involvement, recognition of male teachers, involvement in the school environment, interaction of male teachers, supporting male teachers, and being a role model and a mentor. It is, therefore, crucial for school management to improve job satisfaction among male teachers. In the light of the above statement, this study calls for school management to support their male teachers so that they can release their potential in the performance of their tasks to develop our learners as future leaders for our country, South Africa. 


\section{Conflicts of Interest}

There was no conflict of interest from the authors during any part of this research.

\section{Funding Statement}

The authors funded the publication of the article themselves.

\section{Reference List}

1. Aliakbari, A. 2015. The impact of job satisfaction on teachers' mental health: A case study on the teachers of Iranian Mazandaran Province. World Scientific News, 1(11):1-11.

2. Ärlestig, H. 2007. Principals' communication inside schools: A contribution to school improvement. The Education Forum, 71(3): 262-273.

3. Azeem, S.M. 2010. Job satisfaction and organizational commitment among employees in the Sultanate of Oman. Scientific Research Psychology, 1(4), October: 295-299.

4. Balfour, R.J. 2013. Our education needs an extreme makeover. Available at: http://news.nwu.ac.za/oureducation-needs-extreme-makeover (Accessed 16 January 2016).

5. Belle, L. J. 2007. The role of secondary school principals in motivating teachers in the Flacq District of Mauritius. Pretoria: UNISA.

6. Berry, B. Smylie, M. \& Fuller, E. 2008. Understanding teacher working conditions: A review and look to the future. Hillsborough, NC: Centre for Teaching Quality.

7. Brill, F., Grayson, H., Kuhn, L., \& O'Donnell, S. 2018. What impact does accountability have on Curriculum, standards and engagement in Education? A literature review. Slough: NFER. ISBN-978-1-911039-81-5. (Accessed on 17 May 2018).

8. Buchbinder, B.B. \& Shanks, N.H. 2007. Introduction to health care management. Boston: Jones and Bartlett Publishers.

9. California County Superintendents Educational Services Association. 2016. Best Practices in Teacher and Administrator Induction Programs. Research Presentation.

10. Carl, A. 2010. Teacher empowerment through curriculum development: Theory into practice. 3rd ed. Cape Town: Juta \& Company Ltd.

11. Carstens, S. 2005. Are schools a disaster without men? Available at: http://www.rapport.co.za (Accessed on 27 August 2013).

12. Cheng, C. 2008. The effect of shared decision-making on the improvement in teachers' job development. New Horizons in Education, 53(3), December: 31-46.

13. Corkin, D. M., Ekmekci, A., \& Parr, R. 2018. The Effects of the School-Work Environment on Mathematics Teachers' Motivation for Teaching: A Self-Determination Theoretical Perspective. Australian Journal of Teacher Education, 43(6).

14. Edgerson, D.E. \& Kritsonis, W.A. 2006. Analysis of the influence of principal-teacher relationships on student academic achievement: A national focus. National Journal for Publishing and Mentoring Doctoral Student Research, 1(1): 1-5. 
15. Education Labour Relations Council. 2005. Study of demand and supply of teachers in South African public schools: Potential for Attention. [Online] Available at: http://www.elrc.co.za/News.asp?SectID=4 (Accessed on $16 / 06 / 13)$.

16. Emsley, R., Emsley, L. \& Seedat, S. 2009. Occupational disability on psychiatric grounds in South African schoolteachers. African Journal of Psychiatry, 8(12), August: 223-226.

17. Field, A. 2009. Discovering statistics using SPSS. 3rd ed. London: SAGE.

18. Fuller, E.J., Young, M.D. \& Baker, B. 2011. Examining the impact of school leaders and their preparation on teacher quality and student achievement. Educational Administration Quarterly, 47:173-216.

19. Gina, N. 2018. Provincial Education Departments Performance Indicators: roundtable discussion - Basic Education. Available at: https.//pmg.org.za-committee-meeting. (Accessed on 06 February 2018).

20. Glover, T.A., Nugent, G.C., Chumney, F.L., Ihlo, T., Shapiro, E.S., Guard, K., Koziol, N. \& Bovaird, J. 2016. Investigating rural teachers' professional development, instructional knowledge, and classroom practice. Journal of Research in Rural Education, 31(3):1-16.

21. Hasbay, D. \& Altindag, E. 2018. Factors that affect the performance of teachers working in secondary-level education. Academy of Educational Leadership Journal, 22(1): 1-19.

22. Heiney-Smith, J. \& Denton, D.W. 2015. Mentoring as professional development: enhancing mentor programs to impact student achievement. Curriculum in Context, Spring: 15-19.

23. Herzberg, F., Mausner, B. \& Snyderman, B.B. 1993. The motivation to work. New Brunswick: Transaction Publishers.

24. Hutabarat, W. 2015. Investigation of teacher job-performance model: Organizational culture, work motivation and job satisfaction. Journal of Asian Social Science, 11(18):295-304.

25. Khalil, M.I.K. 2013. Job satisfaction and work morale among PhDs. International Review of Management and Business Research, 2(2), August: 362-370.

26. Kiggundu, E. \& Nayimuli, S. 2009 Teaching practice: A make or break phase for student teachers. South African Journal of Education, 29: 345-358.

27. Latif, K., Shahid, M.N., Sohail, N. \& Shahbaz, M. 2011. Job satisfaction among public and private college teachers of District Faisalabad, Pakistan: A comparative analysis. Interdisciplinary Journal of Contemporary Research in Business, 3(8), December: 235-242.

28. Leithwood, K. 2006. Teacher working conditions that matter: Evidence for change. Toronto: Elementary Teachers' Federation of Ontario.

29. Maforah, T.P. \& Schulze, S. 2012. The job satisfaction of principals of previously disadvantaged schools: new light on an old issue. South African Journal of Education. 32(3), August: 227-239.

30. Marais, P. 2016. "We can't believe what we see": Overcrowded classrooms through the eyes of student teachers. South African Journal of Education, 6(2): 1-10.

31. Marishane, R.N. \& Botha, R.J. (eds). 2011. School leadership in a changing context: A case for school-based management. Pretoria: Van Schaik.

32. Matjeka, K., Dunsing, R.J. \& McCabe, C. 1999. The empowerment matrix. Manage, 50(2), February: 14-16. 
33. Meador, D. 2019. School issues that negatively impact student learning. (Accessed on 5 July 2019).

34. Mestry, R. 2017. Principals' perspectives and experiences of their instructional leadership functions to enhance learner achievement in public schools. Journal of Education, (69): 257 - 280.

35. Moyo, G., Khewu, N.P.D. \& Bayaga, A. 2014. Disciplinary practices in schools and principles of alternatives to corporal punishment strategies. South African Journal of Education, 34(1): 1-14.

36. Mualuko, N.J., Mukasa, S.A. \& Judy, A.S.K. 2009. Improving decision making in schools through teacher participation. Educational Research and Review, 4(8), August: 391-397.

37. Murage, W.S. \& Kibera, W.L. 2014. Teacher-related factors that influence secondary school teachers job satisfaction levels in public secondary schools in Mombasa District, Kenya. Journal of Education Research and Behavioural Sciences, 3(6), August: 148-153.

38. Msuya, O.W. 2016. Exploring levels of job satisfaction amongst teachers in public secondary schools in Tanzania. International Journal of Educational Administration and Policy Studies, 8(2):9-16.

39. Naidoo, P. \& Petersen, N. 2016. Towards a leadership programme for primary school principals as instructional leaders. South African Journal of Childhood Education, 5(3).

40. Nganzi, C. 2014. Factors influencing secondary school teachers' job satisfaction levels in Lang'ata District, Nairobi-Kenya Department of Education: University of Eldoret. International Journal of Community and Cooperative Studies, 1(2), December: 12-26.

41. Ngobeni, H.W. 2006. The role of the head of department in alleviating work related teacher stress in primary schools. Pretoria: UNISA.

42. Norusis, M.J. 2009. PASW Statistics 18. Guide to data analysis. Upper Saddle River, NJ: Prentice Hall.

43. Omobude, M. \& Igbudu, U. 2012. Influence of teacher participation in decision making on their job performance in public and private secondary schools in Oredo Local Government Area of Edo State, Nigeria. European Journal of Business and Social Sciences, 1(5), August: 12-22.

44. Quan-Baffour, K.P. \& Arko-Achemfour, A. 2013. The effects of lack of career path on job satisfaction among South African teachers. Anthropologist, 15(1): 25-32.

45. Saeed, A. \& Muneer, R. 2012. Work motivation of male and female secondary school teachers in Karachi. Interdisciplinary Journal of Contemporary Research in Business, 4(6), October: 462-467.

46. Salleh, H. \& Tan, C. 2013. Novice teachers learning from others: Mentoring in Shanghai schools. Australian Journal of Teacher Education, 38(3):152-165.

47. Shah, M.J., Rehman, M., Akhtar, G., Zafar, H. \& Riaz, A. 2012. Job satisfaction and motivation of teachers of public educational institutions. International Journal of Business and Social Science, 3(8), April: 271-281.

48. Shaukat, S., Vishnumolakala, V.R. \& Al Bustami, G. 2018. The impact of teachers' characteristics on their selfefficacy and job satisfaction: a perspective from teachers engaging students with disabilities. Available at: https://doi.org/10.1111/1471-3802.12425. (Accessed on 06 November 2018).

49. Shihundla, R.C., Lebese, R.T. \& Maputle, M.S. 2016. Effects of increased nurses' workload on quality documentation of patient information at selected Primary Health Care facilities at Vhembe District, Limpopo Province. Curations, 39(1):1-8 
50. Shumba, J., Rembe, S., Chacko, T. \& Luggya, S. 2016. Mentoring: Reflections of student teachers in one South African university. Journal of Social Sciences, 48(1, 2):71-78.

51. Singh, R. \& Kumar, P. 2012. Survey of job satisfaction and stress among teachers of different faculties of Jawahar Navodaya Vidalayas of India. International Journal of Research Pedagogy and Technology in Education and Movement Sciences, 1(2): 65-76.

52. Singh, R. \& Rawat, H.S. 2010. The study of factors affecting the satisfaction level of private school teachers' in Haryana. Technical and Non-Technical Journal, 1(3), January: 188-197.

53. Smit, T. \& Du Toit, P.H. 2016. Transforming beginner teachers mentoring interventions for social reform. South African Journal of Education, 36(3):1-12.

54. Steyn, G.M. 2002. A theoretical analysis of teacher motivation and morale. Pretoria: UNISA.

55. Swanepoel, C. 2008. The perception of teachers and school principals of each other's disposition towards teacher involvement in school reform. South African Journal of Education, 28: 39-51.

56. Tetik, N. 2016. The effects of psychological empowerment on job satisfaction and job performance of tourist guides. International Journal of Academic Research in Business and Social Sciences, 6(2):221-239.

57. Van Deventer, I. \& Kruger, A.G. 2011. A teacher's guide to school management skills. Pretoria: Van Schaik Publishers.

58. Van Zyl, C. 2011. Teacher migration in South Africa: South African Council for Teachers. Available at: http://www.sace.org.za/upload/files/TeacherMigration Report9June2011.pdf (Accessed on 19 November 2013).

59. Wallin, P. \& Boggan, M. (2015). The Impact of Formal Teacher Mentor Training to Scaffold Beginning Teachers in K-12 Settings. International Journal of Education and Social Science, 2(2): 34-44.

60. Woolfolk, A. 2010. Education psychology. 11th ed. Boston: Pearson Education Inc. 